\title{
Partial purification and characterization of an endothelial cell growth regulator from the bovine ovary*
}

\author{
K. F. Roby and P. F. Terranova \\ Department of Physiology, Ralph L. Smith Research Center, University of Kansas Medical Center, \\ Kansas City, Kansas 66103, USA
}

\begin{abstract}
Summary. An inhibitor of endothelial cell thymidine incorporation in vitro was partly purified from cow ovaries using ammonium sulphate (AS) precipitation. Supernatant fluid from the $100000 \mathrm{~g}$ pellet of freshly homogenized ovaries was subjected to stepwise AS precipitation. Precipitates were collected sequentially at $40 \%, 60 \%, 80 \%$ and $95 \%$ saturation, and then each was dissolved, dialysed $\left(M_{\mathrm{r}} 8000\right.$ cutoff) and examined in tissue culture for effects on cellular thymidine incorporation by cow pulmonary artery endothelial cells (CPAE) and mouse fibroblasts (L929 and 3T3). The 80\% AS precipitate (ppt.) inhibited the in-vitro uptake of $\left[{ }^{3} \mathrm{H}\right]$ thymidine by CPAE and L929 cells, but not 3 T 3 cells. Heparin-Sepharose (HS) chromatography of the $80 \%$ AS ppt. revealed that the inhibitory activity on CPAE and L929 cells did not bind to HS; the inhibitory fraction was found in the HS column breakthrough $(80 \%$ BT). The $80 \%$ BT fraction reduced CPAE $\left[{ }^{3} \mathrm{H}\right]$ thymidine uptake as determined by autoradiography and increased cellular uptake of trypan blue. Serial fractions from Sephacryl S-200 exclusion chromatography of the $80 \%$ BT contained CPAE inhibitory activity in the $M_{\mathrm{s}}$ range 30000 50000 . The inhibitory activity on endothelial cells and L929 fibroblasts and the nonreduced molecular weight range of that fraction are similar to those of tumour necrosis factor alpha (TNF $\alpha$ ). The results indicate that the cow ovary contains a fraction that inhibits endothelial cell growth in vitro and may have important roles in follicular atresia and luteal regression.
\end{abstract}

Keywords: endothelial cell; fibroblast; growth factor; ovary; tumour necrosis factor

\section{Introduction}

Growth of the follicle and corpus luteum is dependent on the growth of the vascular network that nourishes these metabolically active tissues (see Greenwald \& Terranova, 1988). Conversely, follicular atresia and luteal regression are accompanied by involution of the follicular and luteal vascular systems (Lobel \& Levy, 1968; Hay et al., 1976; Niswender et al., 1976; O'Shea et al., 1978). The repeated restructuring of the vascular system is mediated, at least in part, by angiogenic factors in the ovary (Jakob et al., 1977; Gospodarowicz \& Thakral, 1978; Makris et al., 1984; Gospodarowicz et al., 1985; Frederick et al., 1985; Koos, 1986). Extracts of bovine and rabbit corpora lutea were found to be potent stimulators of $\left[{ }^{3} \mathrm{H}\right]$ thymidine uptake by bovine aortic endothelial cells in vitro (Gospodarowicz \& Thakral, 1978). Gospodarowicz et al. (1985) later showed that in the cow this angiogenic activity was fibroblast growth factor (FGF).

Several studies have also indicated the presence of angiogenic factors in ovarian follicles. Nonluteal ovarian tissue from pigs exhibited stimulatory effects on endothelial cell proliferation and

*Reprint requests to Dr P. F. Terranova. 
migration in vitro as well as angiogenic activity in vivo on the chick chorioallantoic membrane (Makris et al., 1984). An angiogenic response to pig follicular fluid (Frederick et al., 1985) and rat granulosa cell conditioned media (Koos, 1986) has also been demonstrated. Ovarian angiogenic factors have been proposed to stimulate and direct the development of blood vessels to follicles and corpora lutea (Findlay, 1986). A growth regulator directing the regression of blood vessels in the ovary has yet to be described. However, tumour necrosis factor (TNF), known to reduce endothelial cell proliferation (Sato et al., 1986; Schweigerer et al., 1987) and migration (Mano-Hirano et al., 1987), has been immunohistochemically demonstrated in cow and rat ovaries (Roby \& Terranova, 1989), has been reported to be produced by lipopolysaccharide (LPS)-stimulated corpora lutea in the rabbit (Bagavandoss et al., 1988) and has significant effects on ovarian steroidogenesis in the rat (Emoto \& Baird, 1988; Roby \& Terranova, 1988; Adashi et al., 1989). It was the intent of this study to examine the cow ovary for the presence of factors that might alter endothelial cell growth in vitro.

\section{Materials and Methods}

\section{Ovaries: source and extraction}

Ovaries from beef cattle were obtained from the Department of Animal Science at the University of Missouri, Columbia, Missouri, or from The State of Kansas Meat Plant at Oskaloosa, Kansas. The ovaries were kept on ice for 4-6h until snap frozen on solid $\mathrm{CO}_{2}$ and were maintained at $-80^{\circ} \mathrm{C}$ until subjected to extractions.

The ovaries were kept at $4^{\circ} \mathrm{C}$ throughout the extraction procedure. The ovaries were used irrespective of stage in the oestrous cycle and therefore contained large and small follicles and corpora lutea. Ovaries $(\sim 300 \mathrm{~g})$ were cut into small pieces with a scalpel and then homogenized in 1.5 volumes $(\mathrm{w} / \mathrm{v}) 0.01 \mathrm{M}$-Tris- $\mathrm{HCl}$ buffer, $\mathrm{pH} 7.0$. The homogenate was centrifuged at $10000 \mathrm{~g}$ for $30 \mathrm{~min}$. The resulting pellet was discarded and the supernatant fluid was centrifuged at $100000 \mathrm{~g}$ for $60 \mathrm{~min}$. The supernatant fluid $(\sim 540 \mathrm{ml})$, from which $10 \mathrm{ml}$ were saved as crude supernatant, was subjected to sequential precipitation by addition of ammonium sulphate to a final concentration of $40 \%, 60 \%$, $80 \%$ and $95 \%$. For precipitation, ammonium sulphate was slowly added to the supernatant with stirring until the desired final concentration was reached. The mixture was incubated for $10 \mathrm{~min}$ at $4^{\circ} \mathrm{C}$ with stirring and then centrifuged for $15 \mathrm{~min}$ at $10000 \mathrm{~g}$. The supernatant fluid was subjected to the next addition of ammonium sulphate. The precipitate was dissolved in the smallest volume of Tris buffer that resulted in a clarified fluid. Each dissolved precipitate, referred to as " $\%$ ppt.", was dialysed (cutoff $M_{\mathrm{r}} 8000$ ) against Tris buffer at $4^{\circ} \mathrm{C}$ overnight (dialysate:buffer 1 : 100). The buffer was changed once after $6 \mathrm{~h}$ of dialysis. Then, each dialysate was clarified by centrifugation $(10000 \mathrm{~g}$, $15 \mathrm{~min}$ ) to remove and discard any precipitate that may have formed during dialysis. Each dialysate was examined for effects on cellular incorporation of $\left[{ }^{3} \mathrm{H}\right]$ thymidine in vitro.

\section{Cell culture}

Endothelial cells. Cow pulmonary artery endothelial cells (CPAE, supplied by Una Ryan, University of Miami, Miami, Florida) were maintained in Dulbecco's Modified Eagle Medium (DMEM, Gibco Laboratories, Grand Island, NY, USA) supplemented with 10\% fetal calf serum (FCS, Sigma, St Louis, MO, USA), 50 U penicillin/ml and $50 \mu \mathrm{g}$ streptomycin/ml (Irvine Scientific, Santa Ana, CA, USA) and Ryan red (Ryan \& Maxwell, 1986) at a concentration of $50 \%$.

Fibroblast cells. BALB/c mouse embryo fibroblasts ( 3 T3 cells) and the transformed mouse fibroblast (L929) (CCL 163 and CCL 1, respectively, American Type Culture Collection, Rockville, MD, USA) were maintained in DMEM supplemented with $10 \%$ FCS and antibiotics.

Thymidine incorporation assay. The classical in-vitro assay to detect the presence of TNF $\alpha$ in fluids is the L929 cell lytic assay (Carswell et al., 1975; Ruff \& Gifford, 1980; Aggarwal et al., 1985). The inhibitory activity of TNF $\alpha$ on L929 cells has been quantitated using cellular uptake of $\left[{ }^{3} \mathrm{H}\right]$ thymidine, uptake of trypan blue, exclusion of crystal violet, or the release of ${ }^{51} \mathrm{Cr}$ (Ruff \& Gifford, 1980; Aggarwal et al., 1985).

The media from confluent $25 \mathrm{~cm}^{2}$ flasks of 3T3, CPAE and L929 cells were removed and the cells were washed once with Hanks Balanced Salt Solution (HBSS, calcium and magnesium free; Gibco Laboratories) and then trypsinized with $0.25 \%$ trypsin in $5 \mathrm{ml}$ HBSS. The cells were incubated with the trypsin for $10 \mathrm{~min}$ and then with $1 \mathrm{ml} \mathrm{FCS}$. The cells, in suspension, were centrifuged at $100 \mathrm{~g}$ for $10 \mathrm{~min}$. The supernatant was removed and the cells were diluted to the desired density with DMEM supplemented with $10 \%$ FCS. For assay, cells were seeded in 96-well flat bottomed trays (Fisher, St Louis, MO, USA) at a density of either $20000 \mathrm{~L} 929$ cells $/ 200 \mu \mathrm{l} /$ well or $100003 \mathrm{~T} 3$ and CPAE cells/ $200 \mu \mathrm{l} /$ well. After an overnight incubation allowing for cellular attachment, the media were removed and the cells were washed twice with $300 \mu \mathrm{l}$ DMEM without serum. Fresh DMEM $(20 \mu 1)$ without serum and the $50 \mu \mathrm{l}$ sample to be 
tested were added. All samples were diluted to the desired concentration with DMEM and tested in triplicate. After incubation for $48 \mathrm{~h}, 1 \mu \mathrm{Ci}\left[{ }^{3} \mathrm{H}\right]$ thymidine (ICN Radiochemicals, Irvine, CA, USA; sp. act. $59 \mathrm{Ci} / \mathrm{mmol}$ ) in $10 \mu \mathrm{l}$ DMEM was added to each well for 4 (L929) or $24 \mathrm{~h}$ (CPAE or 3T3). After the incubation with $\left[{ }^{3} \mathrm{H}\right]$ thymidine, media were removed, the cells were washed once with HBSS and then loosened from the culture surface by incubation for 15 min with $200 \mu 10 \cdot 25 \%$ trypsin in HBSS. The cells were then harvested onto glass-fibre filter paper with an automated cell harvester (No. 7019, Skatron Inc., Sterling, VA, USA). Radioactivity in the nuclear fraction of the cells was determined by liquid scintillation.

\section{Chromatography}

All column chromatographic procedures were performed at $4^{\circ} \mathrm{C}$. Heparin-Sepharose CL-6B (HS) (Pharmacia, Piscataway, NJ, USA) was swollen for $1 \mathrm{~h}$ in $40 \mathrm{ml}$ Tris buffer per $1 \mathrm{~g}$ HS and then washed with 5 changes of buffer. Excess buffer was removed from the HS and then the HS was incubated with the $80 \%$ AS ppt. for $1 \mathrm{~h}$ with gentle shaking. The HS was poured into a $10 \mathrm{ml}$ column $(1.5 \mathrm{~cm} \times 6 \mathrm{~cm})$ and the breakthrough (BT) was collected. The protein bound to the $\mathrm{HS}$ (BO) was eluted from the column at $15 \mathrm{ml} / \mathrm{h}$ with a $2 \mathrm{M}-\mathrm{NaCl}-\mathrm{Tris}$ buffer step (approximately 2 column volumes collected as a single fraction). Fractions were diluted and assayed in triplicate in the $\left[{ }^{3} \mathrm{H}\right]$ thymidine incorporation assays.

The breakthrough of the $80 \%$ AS ppt. $(80 \%$ BT) which was generated from the heparin-Sepharose column was applied to a Sephacryl S-200 column $(100 \mathrm{ml}$ packed volume, $1.5 \mathrm{~cm} \times 110 \mathrm{~cm}$; Sigma) equilibrated with $0.01 \mathrm{M}$ phosphate buffer saline (PBS) buffer. The Sephacryl column was precalibrated with the following standards: bovine albumin $\left(M_{\mathrm{r}} 66000\right)$, carbonic anhydrase $\left(M_{\mathrm{r}} 29000\right)$, cytochrome $\mathrm{C}\left(M_{\mathrm{r}} 12400\right)$, and aprotinin $\left(M_{\mathrm{r}} 6500\right)$ (Sigma). Buffer was pumped through the column at $15 \mathrm{ml} / \mathrm{h}, 2 \cdot 5-\mathrm{ml}$ fractions were collected and aliquants were tested in cell culture for effects on $\left[{ }^{3} \mathrm{H}\right]$ thymidine incorporation into CPAE cells.

\section{Autoradiography}

For autoradiography, 20000 CPAE cells were seeded in $400 \mu$ DMEM containing $10 \%$ FCS in 4-chamber plastic slides (Thomas Scientific, Swedesboro, NJ, USA). After overnight incubation for cellular attachment, the cells were washed twice, $400 \mu \mathrm{l}$ each, with serum-free DMEM. Then $400 \mu \mathrm{l}$ DMEM without serum were added, followed by the addition of $100 \mu \mathrm{l}$ diluted sample. After incubation for $48 \mathrm{~h}, 1 \mu \mathrm{Ci}\left[{ }^{3} \mathrm{H}\right]$ thymidine in $10 \mu \mathrm{l}$ DMEM was added. After $24 \mathrm{~h}$ the media were removed and the cells were fixed in methanol twice for periods of 5 min each (Klagsburn et al., 1977). After 4 washes with tap water, cold $5 \%$ trichloroacetic acid (TCA) was added twice for periods of 10 min each, followed by 4 washes with water. The chamber apparatuses were removed from the slides and the slides were dipped in NTB2 nuclear track emulsion (Kodak, Rochester, NY, USA) and exposed in the dark for 3 days. The emulsioncoated slides were developed in Dektol and then fixed. The percentage of labelled cells was determined by counting the labelled and unlabelled cells in 10 microscope fields, with each field containing more than 10 cells. The percentage of labelled cells (no. labelled/total no.) $\times 100$ was determined for each field and the mean \pm s.e.m. for 10 fields was calculated.

\section{Trypan blue exclusion}

CPAE cells were washed and plated as described above for autoradiography. At $18 \mathrm{~h}$ after the addition of $80 \%$ BT, the media were removed and $400 \mu$ trypan blue were added. The numbers of cells stained with trypan blue (dead cells) and excluding trypan blue were counted.

\section{Tumour necrosis factor}

Human recombinant tumour necrosis factor- $\alpha$ (TNF) lot L9009AX, was supplied by Genentech Inc., South San Francisco, CA, USA. The specific activity of TNF determined by in-vitro LM fibroblast cell lysis was $4.03 \times 10^{7} \mathrm{U} /$ $\mathrm{mg}$ and endotoxin present in the preparation was $\leqslant 0.06 \mathrm{EU} / \mathrm{mg}$ as determined by the Limulus amoebocyte lysate (LAL) assay. These determinations were made by Genentech Inc. and provided on the data sheet that accompanied the TNF $\alpha$.

\section{Protein determination}

Protein determinations were made using the Bio-Rad Protein Assay of Bradford (1976) (Bio-Rad Laboratories, Richmond, CA, USA).

\section{Statistical analysis}

A total of 12 different batches of ovaries were extracted for these experiments. Data are presented as the mean \pm s.e.m. of determinations from 3 replicate cultures within each treatment group and are derived from a single experiment. Observations were confirmed in 3-8 independent experiments Student's $t$ test was used to detect differences $10: 13: 08 \mathrm{AM}$ 
between means in some experiments. When appropriate, data were analysed by 1-way or 2-way analysis of variance (ANOVA) followed by Duncan's Multiple Range Test. Values were considered significant when $P \leqslant 0.05$.

\section{Results}

\section{Ammonium sulphate extraction}

CPAE cells (Fig. Ia). At high protein concentration, $\left[{ }^{3} \mathrm{H}\right]$ thymidine uptake was significantly less $(P<0.001)$ with the $80 \%$ AS ppt. when compared with $0 \%$ FCS controls. At the lowest protein concentrations of the $80 \%$ AS ppt., the uptake of $\left[{ }^{3} \mathrm{H}\right]$ thymidine was significantly greater $(P<0.05)$ than $0 \%$ FCS. The $40 \%$ AS ppt. increased the uptake of $\left[{ }^{3} \mathrm{H}\right]$ thymidine incorporation compared to $0 \%$ FCS. $\left[{ }^{3} \mathrm{H}\right]$ thymidine incorporation by CPAE cells was stimulated at the high protein concentrations with the $60 \%$ and $95 \%$ AS ppts. Higher protein concentrations of the 40 and $95 \%$ AS ppts could not be tested due to their low solubility.

3 T3 cells (Fig. 1 b). No inhibitory effect on the uptake of $\left[{ }^{3} \mathrm{H}\right]$ thymidine by $3 \mathrm{~T} 3$ cells was observed with any AS ppt. $(40 \%, 60 \%, 80 \%$ and $95 \%)$. Stimulation of $\left[{ }^{3} \mathrm{H}\right]$ thymidine uptake was observed with at least one concentration of the AS ppts tested.

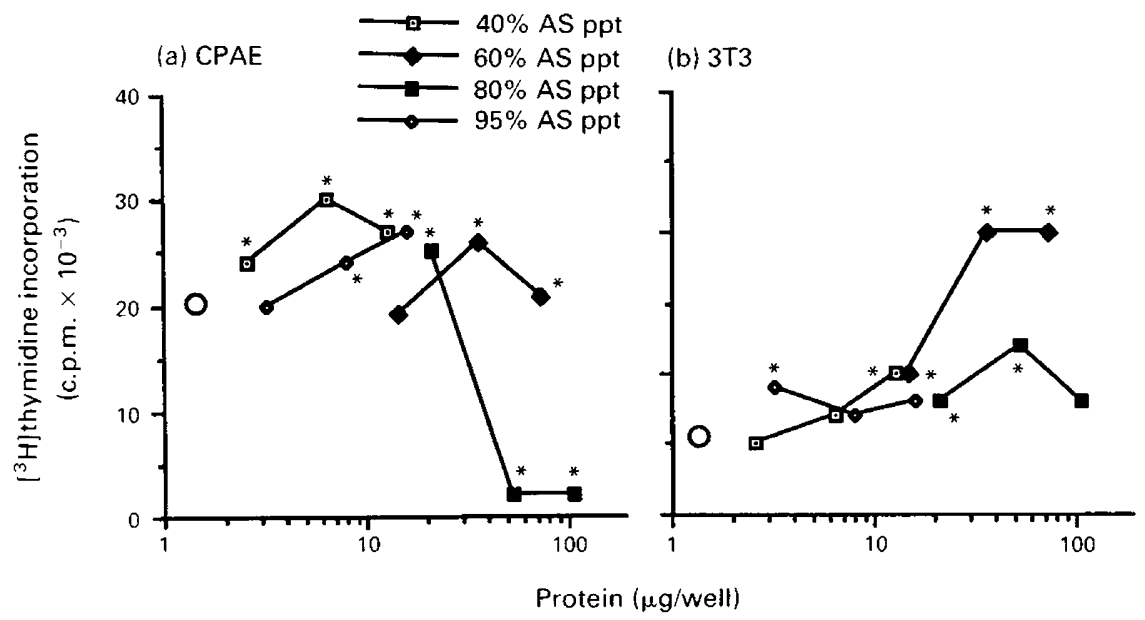

Fig. 1. Effects of the 40-95\% ammonium sulphate (AS) precipitates on $\left[{ }^{3} \mathrm{H}\right]$ thymidine incorporation by cow pulmonary artery endothelial (CPAE) cells (a) and fibroblast (3T3) cells (b). The basal level of $\left[{ }^{3} \mathrm{H}\right]$ thymidine uptake in response to media alone is indicated by the open circles. Values are the mean \pm s.e.m. of 3 replicate cultures derived from a single experiment and are representative of 3 independent experiments. $\left[{ }^{3} \mathrm{H}\right]$ thymidine incorporation in response to various AS precipitates was considered statistically different from that in response to $0 \%$ FCS (control) when the $P$ value was $\leqslant 0.05$ as determined by Student's $t$ test. AS ppt. versus $0 \%$ FCS: ${ }^{*} P<0.05$.

\section{Heparin-Sepharose chromatography}

CPAE cells (Fig. 2). The portion of the $80 \%$ ppt. that exhibited inhibitory effects $(P<0.001)$ on CPAE cell uptake of $\left[{ }^{3} \mathrm{H}\right]$ thymidine did not bind the HS but was contained in the breakthrough (80\% BT) (Fig. 2). Dilution of the $80 \%$ BT to $\sim 2 \mu \mathrm{g} /$ well stimulated $(P<0.05)\left[{ }^{3} \mathrm{H}\right]$ thymidine uptake by the CPAE cells. That portion of the $80 \%$ fraction bound to the $\mathrm{HS}(80 \% \mathrm{BO})$ which was eluted by a $2 \mathrm{M}$ salt step did not alter $\left[{ }^{3} \mathrm{H}\right]$ thymidine incorporation compared to $0 \% \mathrm{FCS}$.

3 T3 cells (Fig. $3 a$ ). At the protein concentrations tested, the $80 \%$ AS ppt., $80 \%$ BT or $80 \%$ BO did not inhibit the uptake of $\left[{ }^{3} \mathrm{H}\right]$ thymidine by $3 \mathrm{~T} 3$ cells. The $80 \%$ AS ppt. and the $80 \%$ BT stimulated thymidine uptake (Fig. 3a) by 3 T 3 cells. 


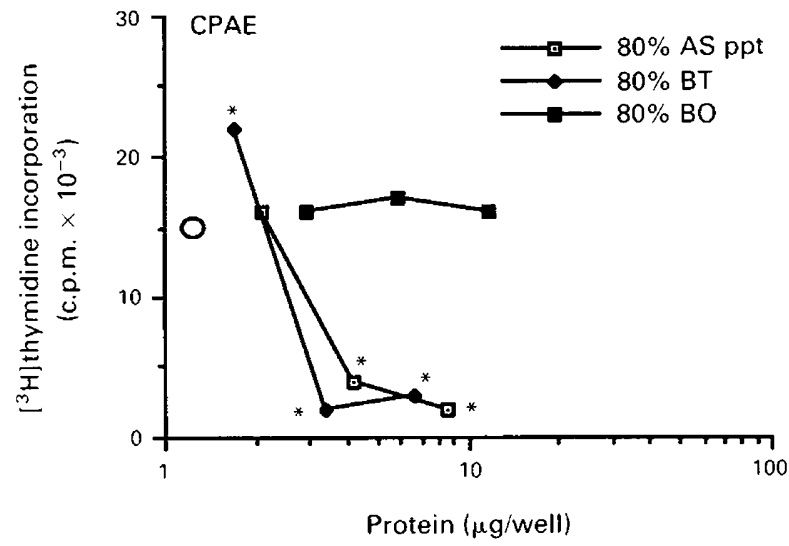

Fig. 2. Effects of $80 \%$ AS ppt., $80 \%$ heparin-Sepharose column breakthrough $(80 \% \mathrm{BT})$, and $80 \%$ heparin-Sepharose column bound $(80 \% \mathrm{BO})$ on $\left[{ }^{3} \mathrm{H}\right]$ thymidine incorporation by CPAE cells. The values are the mean \pm s.e.m. of 3 replicate cultures derived from a single experiment and are representative of 6 independent experiments. The basal level of $\left[{ }^{3} \mathrm{H}\right]$ thymidine uptake in response to medium alone is indicated by the open circle. AS ppt. versus $0 \%$ FCS: ${ }^{*} P<0 \cdot 05$.

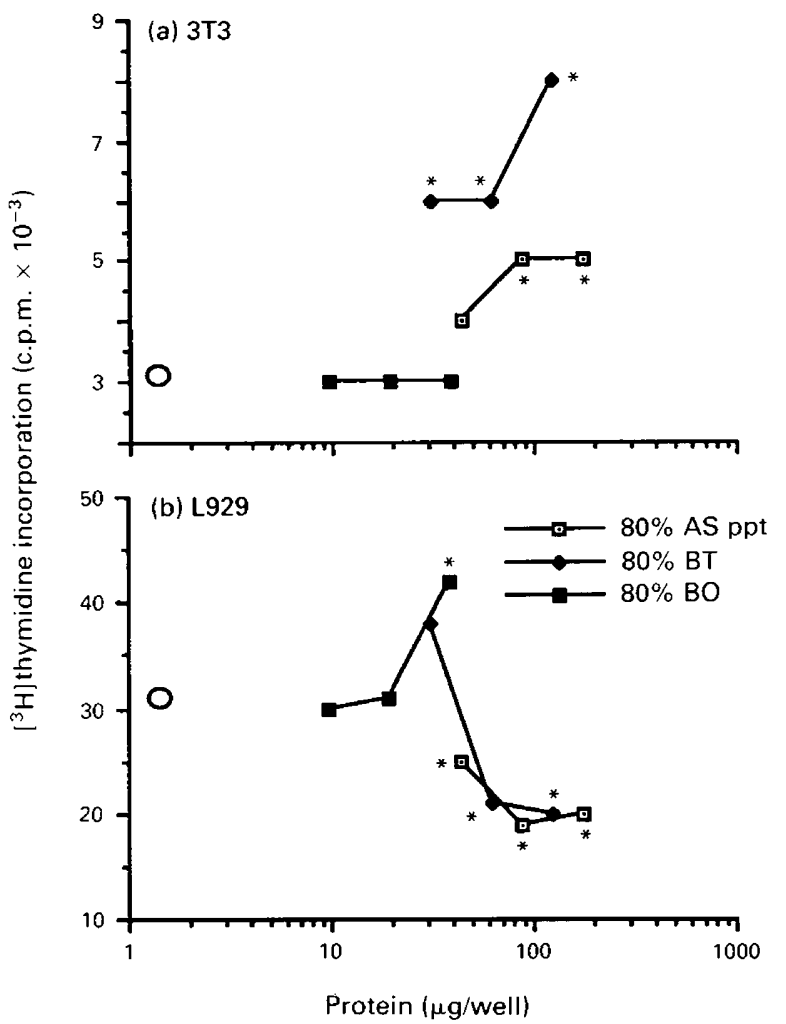

Fig. 3. Effects of $80 \%$ AS ppt., $80 \%$ heparin-Sepharose column breakthrough $(80 \% \mathrm{BT})$, and $80 \%$ heparin-Sepharose column bound $(80 \% \mathrm{BO})$ on $\left[{ }^{3} \mathrm{H}\right]$ thymidine incorporation by (a) 3T3 cells and (b) L929 cells. Values are the mean \pm s.e.m. of 3 replicate cultures derived from a single experiment and are representative of 4 independent experiments. The basal level of $\left[{ }^{3} \mathrm{H}\right]$ thymidine uptake in response to medium alone is indicated by the open circles. AS ppt. versus $0 \%$ FCS: ${ }^{*} P<0.05$. 


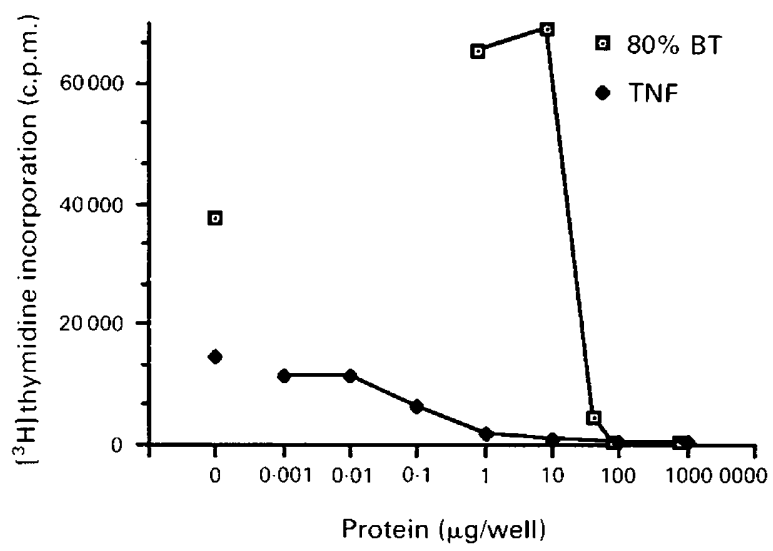

Fig. 4. The effect of various amounts of $80 \%$ BT and human recombinant TNF $\alpha$ on $\left[{ }^{3} \mathrm{H}\right]$ thymidine incorporation by CPAE cells. Values are the mean \pm s.e.m. of 3 replicate cultures derived from a single experiment and are representative of 3 independent experiments.

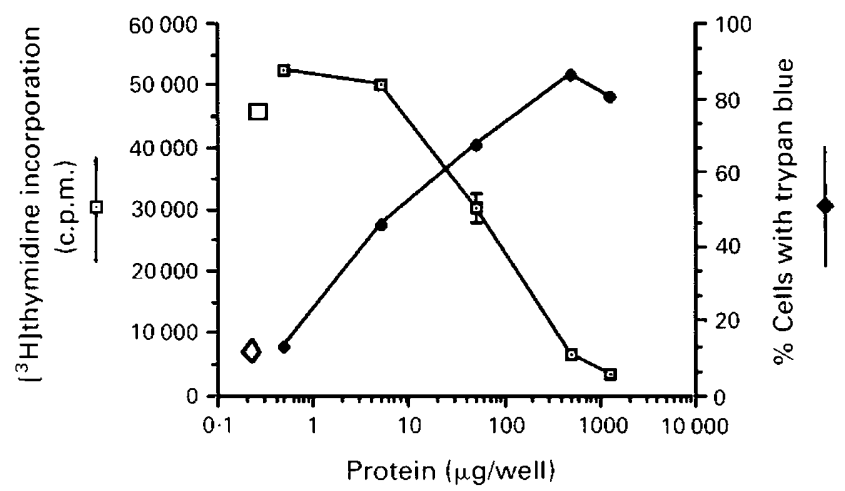

Fig. 5. The effect of $80 \%$ BT on CPAE cell trypan blue uptake and $\left[{ }^{3} \mathrm{H}\right]$ thymidine incorporation. After $18 \mathrm{~h}$ of incubation with the $80 \%$ BT, CPAE cells were stained with trypan blue, and the percentage stained (no. cells stained/total no. cells $\times 100$ ) was determined. In a parallel study after $18 \mathrm{~h}$ of incubation with $80 \% \mathrm{BT}$, CPAE cells were pulsed for $4 \mathrm{~h}$ with $\left[{ }^{3} \mathrm{H}\right]$ thymidine to determine thymidine incorporation. Control levels of trypan blue uptake and $\left[{ }^{3} \mathrm{H}\right]$ thymidine incorporation are indicated by the open symbols.

L929 cells (Fig. 3b). Inhibitory effects on L929 cell $\left[{ }^{3} \mathrm{H}\right]$ thymidine incorporation were apparent in the $80 \%$ AS ppt. and $80 \%$ BT fractions. Compared to controls, there was approximately a $60 \%$ reduction in $\left[{ }^{3} \mathrm{H}\right]$ thymidine uptake by the L929 cells at the highest protein concentration of $80 \%$ AS ppt. and $80 \%$ BT tested. The $80 \%$ BO fraction, at the highest protein concentration tested, exhibited stimulatory effects $(P<0.05)$ on $\mathrm{L} 929\left[{ }^{3} \mathrm{H}\right]$ thymidine uptake. With a reduction in protein concentration the $80 \%$ BO fraction did not alter $\left[{ }^{3} \mathrm{H}\right]$ thymidine incorporation compared to controls.

\section{Effects of various amounts of $80 \% \mathrm{BT}$ and TNF}

The $80 \%$ BT and TNF $\alpha$, each reduced the uptake of $\left[{ }^{3} \mathrm{H}\right]$ thymidine by CPAE cells in a dosedependent manner (Fig. 4). CPAE cells appeared to be more sensitive to TNF: 1 ng TNF reduced 


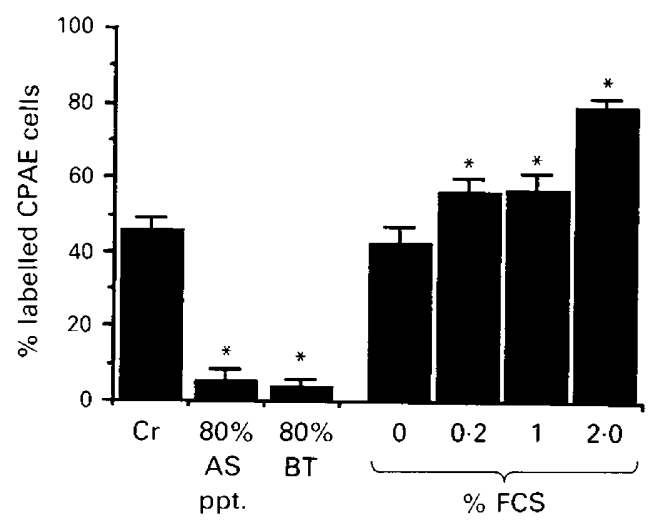

Fig. 6. The percentage labelled CPAE cells (no. labelled/total no. $\times 100$ ) as determined by autoradiography after incubation with crude (Cr), $80 \%$ AS ppt., $80 \% \mathrm{BT}$, or $0,0.2,1 \cdot 0,2.0 \%$ FCS. The percentage indicated is the mean \pm s.e.m. of 10 microscopic fields. Total protein added $/ 500 \mu \mathrm{l}$ was: crude, $76.5 \mu \mathrm{g} ; 80 \%$ AS ppt. $163 \mu \mathrm{g} ; 80 \% \mathrm{BT}, 6.7 \mu \mathrm{g} .{ }^{*} P<0.05,0 \%$ FCS versus treatment, Student's $t$ test.

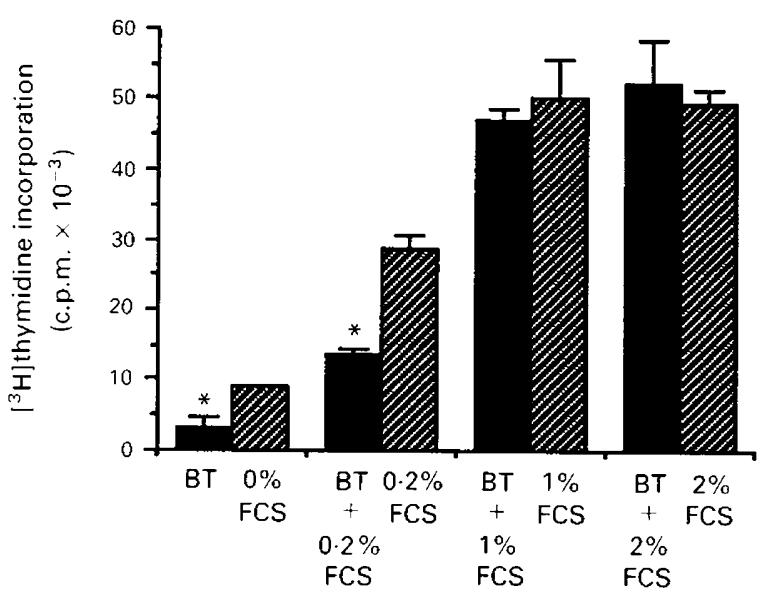

Fig. 7. $\left[{ }^{3} \mathrm{H}\right]$ thymidine incorporation by CPAE cells after incubation with the $80 \% \mathrm{BT}$ fraction plus or minus various amounts of fetal calf serum (FCS). $80 \%$ BT versus serum control, ${ }^{*} P<0.05$ (Student's $t$ test).

thymidine incorporation to $13 \%$ of control values while $40 \mu \mathrm{g}$ were needed to give the same reduction for the $80 \%$ BT fraction.

\section{Effects of $80 \%$ BT on CPAE cell trypan blue uptake and $\left.\right|^{3} \mathrm{H} \mid$ thymidine incorporation}

Increasing concentrations of $80 \%$ BT resulted in a dose-dependent increase in trypan blue uptake by CPAE cells (Fig. 5). The highest dose of $80 \%$ BT resulted in $80.6 \%$ of the CPAE cells staining with trypan blue. The lowest dose of $80 \%$ BT resulted in trypan blue uptake not different from control (13\% and $13 \cdot 8 \%, 80 \% \mathrm{BT}$ and control, respectively). In a parallel study, $\left[{ }^{3} \mathrm{H}\right]$ thymidine incorporation by CPAE cells was reduced in a dose-dependent manner with increasing concentration of $80 \%$ BT. The highest dose of $80 \%$ BT resulted in $10 \%$ [ $\left.{ }^{3} \mathrm{H}\right]$ thymidine incorperation 


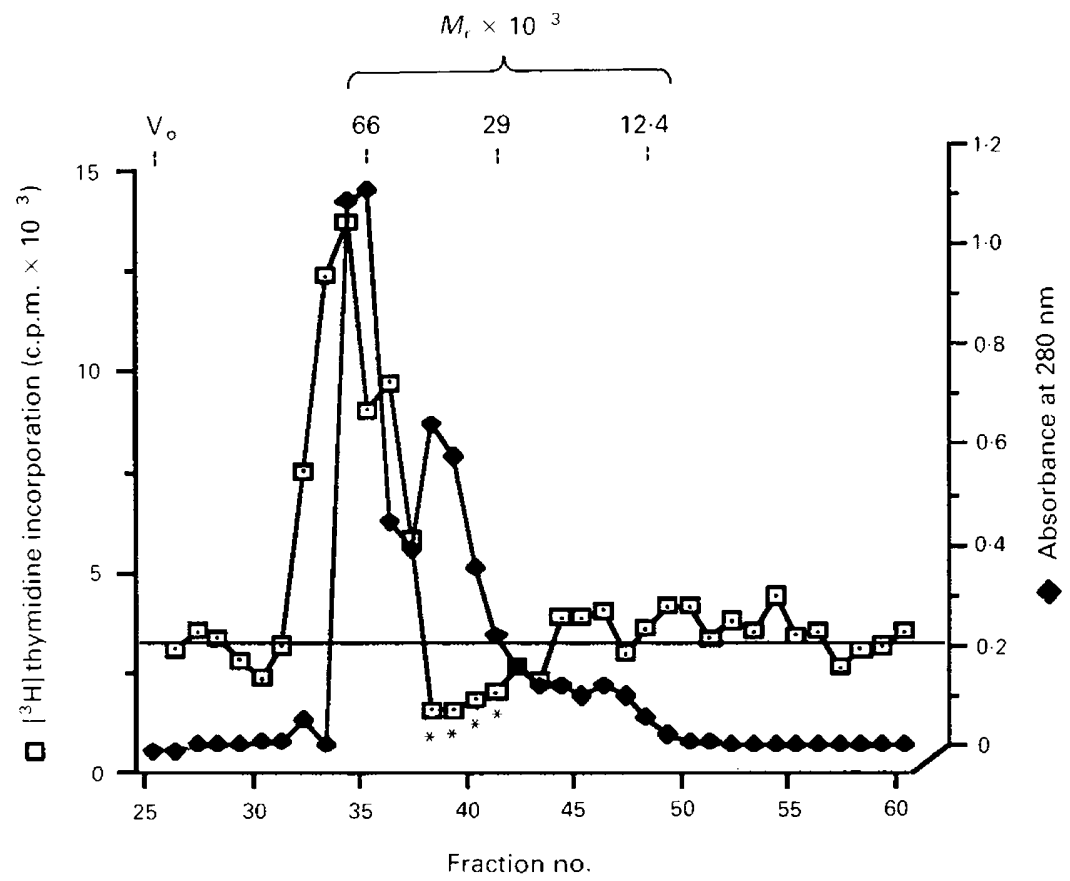

Fig. 8. The effect of Sephacryl S-200 chromatography of the $80 \%$ BT on CPAE cell thymidine incorporation. The $80 \%$ BT was applied to a Sephacryl S-200 column. The horizontal line indicates levels of $\left[{ }^{3} \mathrm{H}\right]$ thymidine incorporation in response to media alone. An inhibitory region of activity corresponds to fractions $39-42$, a molecular weight range of $30000-50000$. The absorbance of each fraction at $280 \mathrm{~nm}$ is indicated. Values are the mean \pm s.e.m. of 3 replicate cultures derived from a single experiment and are representative of 3 independent experiments. An inhibitory region was considered when at least two consecutive fractions exhibited a statistically significant reduction in $\left[{ }^{3} \mathrm{H}\right]$ thymidine incorporation compared with the control of media alone. ${ }^{*} P<0.05$ effect of treatment compared with control.

when compared with control. The lowest dose of $80 \%$ BT resulted in $120 \%$ of the $\left[{ }^{3} \mathrm{H}\right]$ thymidine incorporation compared to control.

\section{Effects of $80 \%$ AS fractions}

Incubation of CPAE cells with the $80 \%$ AS fraction $(163 \mu \mathrm{g})$ resulted in $5.4 \%$ cell labelling with $\left[{ }^{3} \mathrm{H}\right]$ thymidine as assessed by autoradiography (no. of labelled cells/total no. of cells/10 fields, in triplicate wells) (Fig. 6). The $80 \%$ BT fraction $(6.7 \mu \mathrm{g})$ resulted in $3.9 \%$ cell labelling. The control conditions of incubation with media alone resulted in $42 \%$ CPAE cell labelling and incubation with $2 \%$ FCS resulted in $79 \%$ cell labelling with $\left[{ }^{3} \mathrm{H}\right]$ thymidine.

\section{Effects of fetal calf serum and $80 \% \mathrm{BT}$}

The $80 \%$ BT fraction significantly $(P<0.025)$ reduced incorporation of $\left[{ }^{3} \mathrm{H}\right]$ thymidine by CPAE cells compared with controls (Fig. 7). The inhibitory effect of the $80 \%$ BT was still apparent in the presence of $0.2 \%$ FCS. The addition of $1 \%$ or $2 \%$ FCS to the $80 \%$ fraction prevented the reduction in thymidine incorporation by CPAE cells. 


\section{Sephacryl S-200 chromatography of the $80 \%$ BT}

After separation by molecular sieve chromatography, the molecular weight range for the fractions of the $80 \%$ BT that inhibited $\left[{ }^{3} \mathrm{H}\right]$ thymidine uptake by CPAE cells corresponded to fractions 39-42 ( $\left.M_{\mathrm{r}} 30000-50000\right)$ (Fig. 8).

\section{Discussion}

The cow ovary contained a fraction $(80 \%$ ammonium sulphate precipitate) that inhibited the incorporation of $\left[{ }^{3} \mathrm{H}\right]$ thymidine by CPAE and L929 cells yet exhibited a stimulatory effect on $3 \mathrm{~T} 3$ cell thymidine uptake at high and not low protein concentrations. This factor, partly purified from the bovine ovary $(80 \% \mathrm{BT})$, resembles the actions of tumour necrosis factor-alpha (TNF $\alpha$ ) that have been previously reported. The in-vitro bioactivity of TNF $\alpha$ revealed inhibition of $\left[{ }^{3} \mathrm{H}\right]$ thymidine incorporation by endothelial (Sato et al., 1986; Schweigerer et al., 1987) and by L929 cells (Carswell et al., 1975; Ruff \& Gifford, 1980; Aggarwal et al., 1985), and stimulation of $\left[{ }^{3} \mathrm{H}\right]$ thymidine incorporation by 3T3 cells (Sugarman et al., 1985; Vilcek et al., 1986, 1987). The molecular weight range (3000-50000) of the $80 \%$ BT thymidine-incorporation inhibitory activity as determined by Sephacryl S-200 filtration is also similar to TNF $\alpha$ (Fisch \& Gifford, 1983). TNF $\alpha$ has a molecular weight of 17000 under reducing conditions (Pennica et al., 1984; Aggarwal et al., 1985) and 45000 under non-reducing conditions (Aggarwal et al., 1985; Old, 1985; Smith \& Baglioni, 1987). Fisch \& Gifford (1983) have shown that native, non-reduced TNF $\alpha$ elutes from Sephacryl S-200 at a molecular weight of about 48000 .

The extraction procedures utilized were a modification of those used by Gospodarowicz et al. (1985), Folkman et al. (1984) and Beach et al. (1983) for the extraction of endothelial cell growth regulators. TNF $\alpha$ has also been extracted from rabbit serum (Matthews, 1978; Matthews \& Watkins, 1978) and E. coli cell lysates (Bringman \& Aggarwal, 1987) with ammonium sulphate precipitation. A similarity therefore exists between methods for TNF extraction and methods used for the extraction of the $80 \%$ inhibitory activity. TNF $\alpha$ has also been localized immunocytochemically to the follicular and luteal compartments of the cow ovary (Roby \& Terranova, 1989). It is possible that the $80 \%$ inhibitory activity is TNF or a TNF-like fraction. Western blot analysis and neutralization of bioactivity to TNF $\alpha$ are required but sufficient quantities of these specific antisera are at present unavailable.

The $80 \%$ AS ppt. and $80 \%$ BT fractions resulted in inhibition of $\left[{ }^{3} \mathrm{H}\right]$ thymidine incorporation by CPAE and L929 cells only at the highest protein concentrations tested (Figs 1a, 2, 3b). The reason that different protein concentrations were tested among precipitates was due to the different solubilities. The precipitates were dissolved in the smallest volume of buffer to clarify the solution and thus each exhibited a different protein concentration. The thymidine incorporation assays were performed using the maximum protein concentration possible. Upon dilution of the $80 \% \mathrm{BT}$, $\left[{ }^{3} \mathrm{H}\right]$ thymidine incorporation then increased beyond controls and this response was similar to the effect of TNF $\alpha$ on tumour cells (Goeddel et al., 1986). The inhibitory effects of the $80 \%$ AS ppt. and $80 \%$ BT fractions were not entirely due to an excessively high concentration of protein. Various fractions exhibiting similar total protein concentrations did not inhibit thymidine uptake (see Fig. 1, 60\% AS ppt.; Fig. 2, 80\% BO).

Comparison of the $80 \%$ AS ppt. and TNF inhibition of $\left[{ }^{3} \mathrm{H}\right]$ thymidine incorporation by CPAE cells (Fig. 4) indicates that both exhibit similar effects, although the TNF $\alpha$ was more potent. This observation is not unexpected and might be explained by the relative purity of each sample. TNF is a pure recombinant protein while the $80 \% \mathrm{ppt}$. is a protein fraction consisting of several compounds of different molecular weight (see Fig. 8).

Thymidine incorporation into the nuclear fraction was used as a method to assess cellular proliferation. The reduction in $\left[{ }^{3} \mathrm{H}\right]$ thymidine incorporation observed after $80 \%$ fraction treatment may have been due to a decreased number of viable cells. Because cellular incorporation of thymidine does not always correlate with DNA replication and cell division the effects of the $80 \%{ }_{3}$ AS 
ppt and the $80 \%$ BT fractions on cellular thymidine incorporation and viability were further examined by topical autoradiography and trypan blue exclusion. The $80 \%$ AS ppt. and $80 \%$ BT fractions reduced the percentage of CPAE cells that incorporated $\left[{ }^{3} \mathrm{H}\right]$ thymidine as determined by autoradiography. Trypan blue uptake studies indicated an increase in percentage of CPAE cells incorporating the dye following $80 \%$ fraction treatment. Because exclusion of trypan blue by cells indicates cellular viability, these results demonstrate decreased cellular viability after treatment with the $80 \%$ fraction which correlates well with decreased $\left[{ }^{3} \mathrm{H}\right]$ thymidine incorporation (autoradiography and cell harvest method). Collectively these results indicate that the $80 \%$ ppt. and $80 \%$ BT killed the CPAE cells. Future experiments to further confirm the effect of the $80 \%$ fraction on reducing $\left[{ }^{3} \mathrm{H}\right]$ thymidine incorporation should include assessment of cellular DNA. The effect of the $80 \%$ fraction on reducing thymidine incorporation was not overcome by the addition of a small amount $(0 \cdot 1 \%)$ of serum to the culture; however, addition of a greater amount of serum $(1-2 \%)$ resulted in loss of the inhibitory activity. Growth factors present in serum, when added in low concentrations $(0 \cdot 1 \%)$, were unable to overcome the most potent inhibitory effect of the $80 \% \mathrm{BT}$; however, the inhibitory effect of the $80 \%$ BT was overcome by the addition of greater amounts of growth factors (serum). Growth factors in the serum may overcome the effect of the $80 \%$ BT, but it is also possible that binding proteins in the serum may have inactivated the inhibitory compounds. In vivo, plasma may negate the effect of the inhibitory fraction and act as a point of physiological regulation.

What are the possible roles of this inhibitory activity of the $80 \%$ fraction in ovarian function? The inhibitory effect on endothelial cell proliferation might account for the marked difference observed in the vascularization of healthy and atretic follicles (Hay et al., 1976). In the ewe, it has been shown that the inner capillary wreath of atretic follicles was about one-third as vascular and contained $85 \%$ fewer erythrocytes than did non-atretic follicles (Hay et al., 1976). The level of capillary blood flow within the theca of follicles in advanced stages of atresia was significantly less than that in non-atretic follicles (Findlay \& Carson, 1980; Carson et al., 1986). Although alterations in blood flow were not detected in early atresia, another study has shown degenerative changes in the inner capillary network of the theca of primary atretic sheep follicles (O'Shea et al., 1978). The inhibitory effects of the $80 \%$ fraction on the endothelial cells may mediate these vascular changes. The $80 \%$ inhibitory fraction may therefore participate in atresia by altering the follicular vasculature and the integrity of the membrana granulosa which could induce a complement reaction and cause lysis of the granulosa cells as suggested by Farookhi (1981). The ability of the $80 \%$ fraction to stimulate normal fibroblast (3T3) thymidine incorporation might also indicate another possible role for this fraction in atresia. During follicular atresia the thecal layer of the follicle increases in thickness due to cellular hypertrophy, cellular proliferation, and infiltration of fibroblasts ultimately forming the interstitial gland tissue (see Guraya, 1985). The activity of the $80 \%$ fraction may therefore have a physiological role in atresia by stimulating enlargement of the theca and formation of the interstitial gland tissues.

Endothelial cell growth factors extracted from the ovary have been implicated in the development of an extensive vasculature in corpora lutea (Gospodarowicz \& Thakral, 1978; Goodman \& Rone, 1985; Gospodarowicz et al., 1985; Koos, 1986). It also seems possible that an inhibitor of endothelial cell growth could also function to limit growth and/or disrupt the organization of the vasculature during luteal regression. An early change during luteal regression is that the percentage volume of the corpus luteum occupied by vascular elements decreases linearly with time (Niswender et al., 1976). Changes in endothelial cells with luteal regression include nuclear pycnosis and cellular disintegration (Lobel \& Levy, 1968) which are similar to the actions of TNF $\alpha$ on endothelial cells (Sato et al., 1986; Mano-Hirano et al., 1987; Movat, 1987; Sato et al., 1987). The results of the present study indicate that the bovine ovary contains an inhibitor of endothelial cells that exhibits biologically active characteristics similar to TNF $\alpha$ and it may have a role in follicular atresia and luteal regession. 


\section{References}

Adashi, E.Y., Resnick, C.E., Croft, C.S. \& Payne, D.W. (1989) Tumor necrosis factor $\alpha$ inhibits gonadotropin hormonal action in nontransformed ovarian granulosa cells. J. biol. Chem. 264, 11591-11597.

Aggarwal, B.B., Kohr, W.J., Hass, P.E., Moffat, B., Spencer, S.A., Henzel, W.J., Bringman, T.S., Nedwin, G.E., Goeddel, D.V. \& Harkins, R.N. (1985) Human tumor necrosis factor production, purification and characterization. J. biol. Chem. 260, 2345-2354.

Bagavandoss, P., Kunkel, S.L., Wiggins, R.C. \& Keyes, P.L. (1988) Tumor necrosis factor $\alpha$ (TNF $\alpha$ ) production and localization of macrophages and T lymphocytes in the rabbit corpus luteum. Endocrinology 122, 1185-1187.

Beach, R.L., Popoela, H. \& Festoff, B.W. (1983) The identification of neurotropic factor as a transferrin. FEBS Lett. 156, 151-1 56.

Bradford, M. (1976) A rapid and sensitive method for the quantitation of microgram quantities of protein utilizing the principle of protein-dye binding. Analyt. Biochem. 72, 248-254.

Bringman, T.S. \& Aggarwal, B.B.(1987) Monoclonal antibodies to human tumor necrosis factor alpha and beta: application for affinity purification, immunoassays, and as structural probes. Hybridoma 6, 489-507.

Carson, R., Findlay, J., Mattner, P. \& Brown, B. (1986) Relative levels of thecal blood flow in atretic and nonatretic ovarian follicles of the conscious sheep. Aust. J. exp. Biol. med. Sci. 64, 381-388.

Carswell, E.A., Old, L.J., Kassel, R.L., Green, S., Fiore, N. \& Williamson, B. (1975) An endotoxin-induced serum factor that causes necrosis of tumors. Proc. natn. Acad. Sci. USA 72, 3666-3670.

Emoto, N. \& Baird, A. (1988) The effect of tumor necrosis factor/cachectin on follicle-stimulating hormoneinduced aromatase activity in cultured rat granulosa cells. Biochem. Biophys. Res. Commun. 153, 792-798.

Farookhi, R. (1981) Atresia: an hypothysis. In Dynamics of Ovarian Function, pp. 13-23. Eds N. B. Schwartz \& M. Hunzicker-Dunn. Raven Press, New York.

Findlay, J.K. (1986) Angiogenesis in reproductive tissues. J. Endocr. 111, 357-366.

Findlay, J.K. \& Carson, R.S. (1980) Selective binding of gonadotropins and the control of follicular growth and atresia. Adv. Physiol. Sci. 15, 79-89.

Fisch, H. \& Gifford, G.E. (1983) In vitro production of rabbit macrophage tumor cell cytotoxin. Int. $J$. Cancer 32, $105-112$.

Folkman, J., Sullivan, R., Butterfield, C., Murray, J. \& Klagsbrun, M. (1984) Heparin affinity: purification of a tumor-derived capillary endothelial cell growth factor. Science, NY 223, 1296-1299.

Frederick, J.L., Hoa, H., Preston, D.S., Frederick, J.J., Campeau, J.D., Ono, T. \& DiZerega, G.S. (1985) Initiation of angiogenesis by porcine follicular fluid. Am. J. Obstet. Gynecol. 152, 1073-1078.

Greenwald, G.S. \& Terranova, P.F. (1988) Follicular selection and its control. In The Physiology of Reproduction, pp. 387-445. Eds E. Knobil \& J. D. Neill. Raven Press, New York.

Goeddel, D.V., Aggarwal, B.B., Gray, P.W., Leung, D.W., Nedwin, G.E., Sheppard, H.M., Sugarman,
B.J. \& Wong, G.H.W. (1986) Tumor necrosis factors gene structure and biological activities. Cold Spring Harb. Symp. Quant. Biol. 51, 597-609.

Goodman, A.L. \& Rone, J.D. (1985) Detection of angiotropic (chemotractant) activity released by rabbit luteal cells cultured in serum-free or serum-enriched media. Biol. Reprod. (Suppl. 1) 32, 185, abstr.

Gospodarowicz, D. \& Thakral, K.K. (1978) Production of a corpus luteum angiogenic factor responsible for proliferation of capillaries and neovascularization of the corpus lutuem. Proc. natn. Acad. Sci. U.S.A. 72, $847-851$.

Gospodarowicz, D., Cheng, J., Lui, G.M., Baird, A., Esch, F. \& Bohlen, P. (1985) Corpus luteum angiogenic factor is related to fibroblast growth factor. Endocrinology 117, 2383-2391.

Guraya, S.S. (1985) Follicular atresia. In Biology of Ovarian Follicles in Mammals, pp. 228-273. SpringerVerlag, Heidelberg.

Hay, M.F., Cran, D.G. \& Moor, R.M. (1976) Structural changes occurring during atresia in sheep ovarian follicles. Cell. Tiss. Res. 169, 515-529.

Jakob, W., Jentzsch, K.D., Mauersberger, B. \& Oehme, P. (1977) Demonstration of angiogenesis-activity in the corpus luteum in cattle. Exp. Pathol. 13, 231-236.

Klagsbrun, M., Lamger, R., Levenson, R., Smith, S. \& Lillehei, C. (1977) The stimulation of DNA synthesis and cell divsion in chondrocytes and $3 \mathrm{~T} 3$ cells by a growth factor isolated from cartilage. Expl Cell. Res. 105, 99-108.

Koos, R.D. (1986) Stimulation of endothelial cell proliferation by rat granulosa cell conditioned medium. Endocrinology 119, 481-489.

Lobel, B.L. \& Levy, E. (1968) Enzymatic correlates of development, secretory function and regression of follicles and corpora lutea in the bovine ovary. Acta endocr., Copenh., Suppl. 132, 7-33.

Makris, A., Ryan, K.J., Yasumizu, T., Hill, C.L. \& Zetter, B.R. (1984) The nonluteal porcine ovary as a source of angiogenic activity. Endocrinology 115, $1672-1677$.

Mano-Hirano, Y., Sato, N., Sawasaki, Y., Haranaka, K., Satomi, N., Nariuchi, H. \& Goto, T. (1987) Inhibition of tumor-induced migration of bovine capillary endothelial cells by mouse and rabbit tumor necrosis factor. J. natn. Cancer Inst. 78, 115-120.

Matthews, N. (1978) Tumor necrosis factor from the rabbit. II. Production by monocytes. Br. J. Cancer 38, 310-315.

Matthews, N. \& Watkins, J.F. (1978) Tumor necrosis factor from the rabbit. I. Mode of action, specificity and physicochemical properties. Br. J. Cancer 38, 302-309.

Movat, H.Z. (1987) Tumor necrosis factor and interleukin 1: role in acute inflammation and microvascular injury. J. Lab. Clin. Med. 110, 668-681.

Niswender, G.D., Reimers, T.J., Diekman, M.A. \& Nett, T.M. (1976) Blood flow: a mediator of ovarian function. Biol. Reprod. 14, 64-81.

Old, L.J. (1985) Tumor necrosis factor (TNF). Science, NY 230, 630-632.

O'Shea, J.D., Hay, M.F. \& Cran, D.G. (1978) Ultrastructural changes in the theca interna during 
follicular atresia in sheep. J. Reprod. Fert. 54, 183-187.

Pennica, D., Nedwin, G.E., Hayflick, J.S., Seeburg, P.H., Derynck, R., Palladino, M.A., Kohr, W.J., Aggarwal, B.B. \& Goeddel, D.V. (1984) Human tumor necrosis factor: precursor structure, expression and homology to lymphotoxin Nature, Lond. 312, 724-729.

Roby, K.F. \& Terranova, P.F. (1988) Tumor necrosis factor alpha alters follicular steroidogenesis in vitro. Endocrinology 123, 2952-2954.

Roby, K.F. \& Terranova, P.F. (1989) Localization of tumor necrosis factor (TNF) in rat and bovine ovary using immunocytochemistry and cell blot: evidence for granulosal production. In Growth Factors and the Ovary, pp. 273-278. Ed. A. N. Hirshfield. Plenum Press, New York.

Ruf,, M.R. \& Gifford, G.E. (1980) Purification and physicochemical characterization of rabbit tumor necrosis factor. J. Immunol. 125, 1671-1677.

Ryan, U.S. \& Maxwell, G. (19867) Isolation, culture and subculture of bovine pulmonary artery endothelial cells: mechanical methods. J. Tissue Culture Methods 10, 3-6.

Sato, N., Fukuda, K., Nariuchi, H. \& Sagara, N. (1987) Tumor necrosis factor inhibiting angiogenesis in vitro. J. natn. Cancer Inst. 79, 1383-1391.

Sato, N., Goto, T., Haranaka, K., Satomi, N., Nariuchi, H., Mano-Hirano, Y. \& Sawasaki, Y. (1986) Actions of tumor necrosis factor on cultured endothelial cells: morphological modulation, growth inhibition, and cytotoxicity. J. natn. Cancer Inst. 76, 1113-1121.

Schweigerer, L, Malerstein, B. \& Gospodarowicz, D. (1987) Tumor necrosis factor inhibits the proliferation of cultured capillary endothelial cells. Biochem. Biophys. Res. Commun. 143, 997-1004.

Smith, R.A. \& Baglioni, C. (1987) The active form of tumor necrosis factor is a trimer. $J$. biol. Chem. 262, 6951-6954.

Sugarman, B.J., Aggarwal, B.B., Hass, P.E., Figari, I.S., Palladino, M.A. Jr \& Shepard, H.M. (1985) Recombinant human tumor necrosis factor- $\alpha$ : effects on proliferation of normal and transformed cells in vitro. Science, NY 230, 943-945.

Vilcek, J., Palombella, V.J., Henrikson-DeStefano, D., Swenson, C., Feinman, R., Hirai, M. \& Tsujimoto, M. (1986) Fibroblast growth enhancing activity of tumor necrosis factor and its relationship to other polypeptide growth factors. J. exp. Med. 163, 632-643.

Vilcek, J., Tsujimoto, M., Palombella, V.J., Kohase, M. \& Le, J. (1987) Tumor necrosis factor: Receptor binding and mitogenic action in fibroblasts. $J$. cell. Physiol. 5, 57-61.

Received 29 August 1989 